\title{
David Oliver: Lies, damned lies, and the NHS
}

\author{
David Oliver consultant in geriatrics and acute general medicine
}

Berkshire

My school maths teacher got us reading Darrell Huff's seminal How to Lie with Statistics. The lessons have endured. In a similar vein was a wonderful recent column in the Observer by the statistician David Spiegelhalter on nine ways people misuse numbers to support their arguments. ${ }^{1}$ Three of these included recent examples from the NHS.

- Use total numbers rather than proportions. Remember government claims that more emergency department patients than ever were being seen within four hours $?^{2}$ This despite the percentage dropping to a new low as activity rose, ${ }^{3}$ which Jeremy Hunt later conceded. ${ }^{4}$

- Casually imply causation from correlation. Consider categorical government claims that $6000,{ }^{5}$ then 11000 "excess weekend deaths" in hospital were caused by staffing, with no credible data to back this assertion.

- Choose your definitions carefully. Check the claim and counterclaim in 2014's prime minister's questions about the number of NHS nurses, depending on the debaters' choice of time frame. ${ }^{78}$

Consider categorical government claims that 6000 , then 11000 "excess weekend deaths" in hospital were caused by staffing, with no credible data to back this assertion

Spiegelhalter listed six other tricks. I've seen the following five repeatedly employed regarding the NHS.

- Don't provide relevant context. Remember government claims that an additional $£ 3$.8bn had been given to social care thanks to the Better Care Fund? This ignored far larger budgetary cuts and played down the transfer of all funds from existing NHS budgets. ${ }^{9} 10$

- Prematurely announce the success of a policy initiative using unofficial selected data. The coalition government pushed a "three million lives" telecare and telehealth campaign and funded independent "whole systems demonstrator" trials. ${ }^{11}$ Officials announced major benefits before peer reviewed publication and urged mass implementation. ${ }^{12-15}$ The eventual trial results were largely null. ${ }^{16}$
- Make the numbers look big (but not too big). For example, a Daily Telegraph article claimed that "EU health tourists cost the NHS $£ 2 m$ a day." This amount vanishes next to the total NHS annual spend of about $£ 120 \mathrm{bn} .{ }^{17}$

- Exaggerate the importance of a possible illusory change. The government has given local authorities powers to charge an extra $2 \%$ council tax to fund social care. ${ }^{18}$ But the total raised won't get close to the funding gap, and property values show that this further disadvantages the most deprived areas. ${ }^{19}$

- If all else fails, make the numbers up. This year the Department of Health announced that the English NHS was getting the sixth biggest funding increase in its history. ${ }^{20}$ Comparable data are available only since $1975-76$, and the King's Fund showed this year's increase to be the 28th largest in real terms. ${ }^{21}$ I've yet to see a convincing explanation or defence of this claim.

Doctors have some training in critical appraisal of evidence and statistics. Best be vigilant, then, and use it beyond research and clinical practice.

Competing interests: See www.bmj.com/about-bmj/freelancecontributors/david-oliver.

Provenance and peer review: Commissioned; not externally peer reviewed.

Spiegelhalter D. Our nine point guide to spotting a dodgy statistic. Guardian 2016 Jul 17 https://www.theguardian.com/science/2016/jul/17/politicians-dodgy-statistics-tricks-guide. Hunt J. Twitter: More patients than ever being seen in <4 hours. 6 Jan 2014. https://twitter. com/Jeremy_Hunt/status/552481896614338561.

3 Health Foundation. Nuffield Trust. QualityWatch: A\&E waiting times-2014 figures. www. qualitywatch.org.uk/indicator/ae-waiting-times.

4 Watt N, Siddique H. NHS four hour wait time target in A\&E met in $90 \%$ of cases. Guardian 2015 Jan 6. https://www.theguardian.com/society/2015/jan/06/nhs-failing-to-meet-targetshealth-minister-norman-lamb.

5 Mason R, Wintour P. Jeremy Hunt gives NHS consultants ultimatum on weekend working Guardian 2015 Jul 16. https://www.theguardian.com/society/2015/jul/16/nhs-consultantsgiven-ultimatum-on-weekend-working

6 Full Fact. No evidence 11000 weekend deaths are caused by understaffing. 17 Feb 2016. https://fullfact.org/health/no-evidence-11000-nhs-weekend-deaths-are-causedunderstaffing/.

7 BBC News. Prime minister's questions: Cameron and Blenkinsop on numbers of NHS nurses. 17 Dec 2014. www.bbc.co.uk/news/uk-politics-30517458.

8 Campbell D. £3.8bn NHS better care fund policy delayed after damning Whitehall review. Guardian 2014 May 7. https://www.theguardian.com/society/2014/may/06/nhs-bettercare-fund-policy-halted-whitehall-review. 
9 Humphries R. Taking control of our social care system. King's Fund. 13 Jul 2016. www. kingsfund.org.uk/blog/2016/07/taking-control-our-social-care-system.

10 Humphries R. The Better Care Fund: will the plans work? King's Fund. 5 Nov 2014. www. kingsfund.org.uk/blog/2014/11/better-care-fund-will-plans-work.

11 Department of Health. A concordat between the Department of Health and the telehealth and telecare industry. 2012. https://www.gov.uk/government/uploads/system/uploads/ attachment data/file/216757/Concordat-3-million-lives.pdf.

12 Easton J. Let's get serious about telehealth. Health Serv J 2012 Jun 25. www.hsj.co.uk/ opinion/columnists/jim-easton-lets-get-serious-about-telehealth/5046307.article.

13 Ayling M. We have the technology: the changing face of healthcare delivery. Health Serv J Suppl 2012 Nov 29

14 Department of Health. Whole systems demonstrator programme: headline findings: Dec 2011. 5 Dec 2011. www.gov.uk/government/publications/whole-system-demonstratorprogramme-headline-findings-december-2011.

15 Steventon A, Bardsley M, Billings J, et al. Whole System Demonstrator Evaluation Team Effect of telehealth on use of secondary care and mortality: findings from the Whole System Demonstrator cluster randomised trial. BMJ 2012;344:e3874. doi:10.1136/bmj. e3874 pmid:22723612.

16 Hope C. Health tourists costs UK taxpayer nearly £6bn in 8 years. Telegraph $2016 \mathrm{Apr}$ 5. www.telegraph.co.uk/news/2016/04/04/health-tourists-cost-uk-taxpayers-nearly-6billionin-eight-years/.
17 King's Fund. The NHS budget and how it has changed. 15 Jan 2016. www.kingsfund.org. uk/projects/nhs-in-a-nutshell/nhs-budget.

18 Russell V. Spending review: council tax hikes to shore up social care funding. Public Finance 2015 Nov 25. www.publicfinance.co.uk/news/2015/11/spending-review-counciltax-hikes-shore-social-care-funding.

19 Butler P. Vulnerable adults at risk as councils face £1bn social care shortfall. Guardian 2016 Jul 13. https://www.theguardian.com/society/2016/jul/13/vulnerable-adult-socialcare-risk-england-councils-face-1bn-shortfall.

20 Hunt J. A strong NHS needs a strong economy - we should not put that at risk with Brexit. Guardian 2016 Mar 26. https://www.theguardian.com/commentisfree/2016/mar/26/jeremyhunt-brexit-nhs.

21 Appleby J. How does this year's NHS budget compare historically? King's Fund. 11 May 2016. www.kingsfund.org.uk/blog/2016/05/how-does-this-years-nhs-budget-comparehistorically.

Published by the BMJ Publishing Group Limited. For permission to use (where not already granted under a licence) please go to http://group.bmj.com/group/rights-licensing/ permissions 